\title{
Working
}

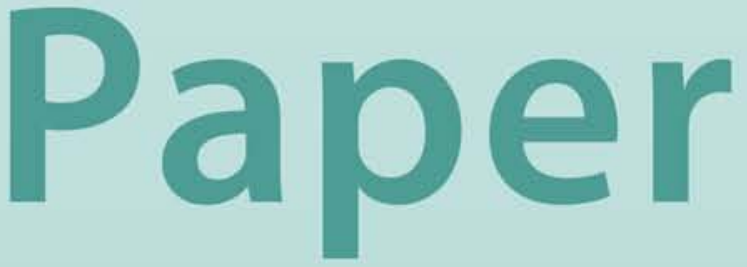


The Cyclical and Long-Term Behavior of Government Expenditures in Developing Countries

Bernardin Akitoby, Benedict Clements, Sanjeev Gupta, and Gabriela Inchauste 


\title{
IMF Working Paper
}

Fiscal Affairs Department and IMF Institute

\section{The Cyclical and Long-Term Behavior of Government Expenditures in Developing Countries}

Prepared by Bernardin Akitoby, Benedict Clements, Sanjeev Gupta, and Gabriela Inchauste ${ }^{1}$

October 2004

\begin{abstract}

\section{This Working Paper should not be reported as representing the views of the IMF.} The views expressed in this Working Paper are those of the author(s) and do not necessarily represent those of the IMF or IMF policy. Working Papers describe research in progress by the author(s) and are published to elicit comments and to further debate.
\end{abstract}

We examine the short- and long-term movements of government spending relative to output in 51 countries. We find that in the short term, the main components of government spending increase with output in about half of the sample countries, with some variation across spending categories and countries. Further, we find that there is a long-term relationship between government spending and output (in line with "Wagner's law") for the majority of countries for at least one spending aggregate. In the short term, we find that power dispersion and government size typically dampen the positive response of government spending to output. Output volatility and financial risk, on the other hand, contribute to the procylicality of government spending.

JEL Classification Numbers: E62; H50; H60

Keywords: Fiscal policy; Business cycles; Wagner’s law

Author(s) E-Mail Address: bakitoby@imf.org; bclements@imf.org; sgupta@imf.org; minchauste@imf.org

\footnotetext{
${ }^{1}$ We would like to thank Rina Bhattacharya and Chris Wu for help and advice in preparing this paper. We received helpful comments from Hamid Davoodi, Eduardo Ley, Clinton Shiells, Irineu de Carvalho Filho, and Evan Tanner on previous drafts of this paper. The usual disclaimer applies.
} 


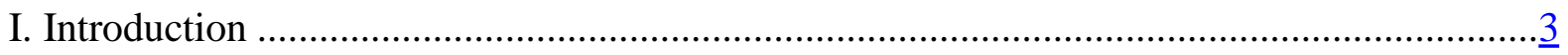

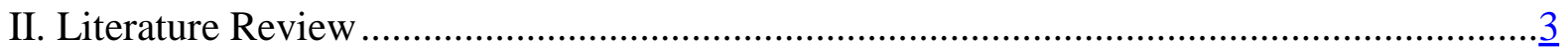

III. A Framework For Analyzing Co-Movements of Government Spending and Output......... $\underline{6}$

A. Estimating the Relationship Between Government Spending and Output .............. 1

B. Modeling Cross-Country Variation in Fiscal Cyclicality ....................................

IV. Empirical Results .......................................................................................... 11

A. Measuring the Short- and Long-Term Elasticity of Government Spending ........... $\frac{11}{16}$

B. Explaining Variations in Short-Term Elasticities Across Countries.......................

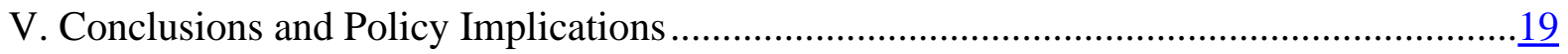

Appendix

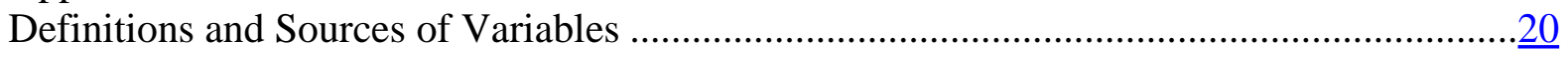

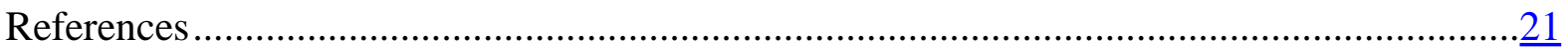

Tables

1. Augmented Dickey Fuller Tests ....................................................................... 12

2. Error-Correction Model: Estimates of Gamma-The Adjustment Coefficient...................13

3. Error-Correction Model: Estimates of Delta-The Long-Term Coefficient......................14

4. Error-Correction Model: Estimates of Beta-The Short-Term Coefficient ....................... $\underline{15}$

5. Determinants of Fiscal Cyclicality.................................................................... 


\section{INTRODUCTION}

Compared with the vast literature on determinants of economic growth, there has been less research on the cyclical behavior of macroeconomic aggregates in developing countries. One reason for this is the relatively weak quality of data and its frequency in many developing countries. For example, quarterly GDP data are available for only a limited number of countries, and even when they are available they are usually of significantly lower quality and reliability than annual estimates. Another constraining factor is that developing countries often experience abrupt economic changes, making it particularly difficult to separate cyclical influences from structural breaks.

A better understanding of the factors underlying the cyclical pattern of macroeconomic aggregates is useful for at least two purposes. First, examining the relationship between overall economic activity and fiscal and monetary aggregates has analytical value from the perspective of business cycle modeling. Second, as Agénor and Montiel (1996) argue, this type of analysis can make a valuable contribution to the design of stabilization and adjustment programs.

This paper makes a contribution to the existing literature in three ways. First, it documents co-movements of government spending and output in developing countries, using data for 51 developing countries. Second, it introduces a novel method-an error-correction approach - to this type of analysis. This approach allows us to distinguish the short-term variations between government spending and output from any longer-term relationship. Third, the paper seeks to explain the observed cross-country variation in the relationship between government spending and output by focusing on key political and economic determinants. With few exceptions (mostly for Latin America), existing studies of developing countries have either focused on the long-run relationship between spending and output, or have examined the volatility of growth and its relationship to the volatility of various fiscal aggregates (see, for example, Fatás and Mihov, 2003), without examining the factors underlying the cyclical behavior of the latter.

\section{LITERATURE REVIEW}

Standard neoclassical and Keynesian approaches suggest that fiscal policy should ideally be countercyclical, with fiscal deficits declining when the economy is expanding and increasing during economic downturns. For example, Barro's (1979) neoclassical analysis of optimal fiscal policy suggests that, for a given path of government spending, tax rates should be held constant over the business cycle, and the budget surplus should move in a procyclical fashion - the "tax smoothing" hypothesis. However, with regard to the cyclicality of government spending, neoclassical theory has little to say: the typical assumption is that government spending is exogenously determined (Lucas and Stokey, 1983; Blanchard and Fischer, 1989; Taylor and Woodford, 1999). The Keynesian approach to optimal fiscal policy reaches a broadly similar result by a different logic. According to this view, policy should, during economic booms, at least accommodate surpluses that emerge from the operation of 
automatic stabilizers and, if necessary, go further with discretionary tax increases or spending cuts.

The empirical evidence from the advanced OECD countries on the cyclical behavior of government spending is mixed. On the one hand, some research shows spending is countercyclical (Gali, 1994), while others show no discernible pattern (Fiorito, 1997; Gavin and Perotti, 1997). The differences in these results depend on the components of spending being measured. For example, Galí (1994) studies government consumption and investment in a simple cross-country regression for a sample of 22 OECD countries and finds that both taxes and government purchases seem to be effectively working as "automatic stabilizers," with government purchases following a countercyclical pattern. Fiorito and Kollintzas (1994) and Fiorito (1997), on the other hand, study specifically government consumption in the G-7 countries and find that the correlation with output shows no pattern and is clustered around zero. Gavin and Perotti (1997) obtain similar results for their sample of industrial countries: they find no statistically significant correlation between total government spending and output fluctuations, with moderately procyclical government consumption being offset by the countercyclical behavior of government subsidies and transfers.

Government transfers and subsidies are found to have become substantially more countercyclical over time. Arreaza, Sørensen, and Yosha (1999) generate panel-based estimates of the degree of cyclicality in government consumption, transfers, subsidies, and tax revenues. Their results suggest that current government expenditures increase during recessions, mainly due to an increase in transfers. Similarly, in another recent study of OECD countries, Lane (2003) finds that current government spending tends to be mildly countercyclical, while government investment spending is procyclical. Moreover, the countercyclicality of current government spending emanates from the behavior of government transfers and/or debt interest payments; the government consumption component of current spending is procyclical.

Some studies have also shown evidence of "cyclical ratcheting" in government spending in OECD countries, with a steady rise in the ratio of government spending to GDP. ${ }^{2}$ Hercowitz and Strawczynski (2004), for example, find evidence of asymmetric government spending over the business cycle: while public spending tends to be countercyclical during recessions, high tax revenues during economic upturns make it politically difficult for governments to resist pressure from interest groups against spending cuts. Not surprisingly, the authors find cyclical ratcheting is particularly high in the case of transfers and subsidies. These findings are consistent with the evidence presented in Gavin and Perotti (1997). They are also consistent with the insights from the theoretical model of Talvi and Végh (2000), which argues that the high variability of fiscal revenues, combined with increased spending

${ }^{2}$ Cyclical ratcheting refers to the tendency of the ratio of government spending to GDP to rise during recessions and to be only partially reduced during expansions. 
pressures in good times, may be key factors in explaining the procyclical nature of fiscal policy.

The limited number of empirical studies for developing countries suggests that government spending tends to be procyclical. For example, Kaminsky, Reinhart, and Végh (2004) find that fiscal policy is procyclical in their subsample of 83 low- and middle-income countries. Similarly, Braun (2001) finds that government expenditure is procyclical in a panel of 35 developing countries for the period 1970-98. Gavin and Perotti (1997) find that in Latin America, total expenditures and its components are highly procyclical, with recessions being associated with exaggerated collapses in public spending. Further support for this is found in Stein, Talvi, and Grisanti (1999), who find an average correlation coefficient of 0.52 between the cyclical component of government consumption and the cyclical component of output over the period 1970-95 for a sample of 26 Latin American countries. Similarly, for their sample of 36 developing countries in Asia, Africa, the Middle East, and Latin America, Talvi and Végh (2000) find that government consumption is highly procyclical, with a correlation coefficient of 0.53. By contrast, Agénor, McDermott, and Prasad (1999) find that government consumption expenditure is countercyclical for a group of four middle-income countries including Chile, Korea, Mexico, and the Philippines.

Difficulties in implementing countercyclical policy may be the cause of procyclical government spending in some countries. One such factor is the structure of the budget. Developing countries have few automatic stabilizers built into their budgets, which would lead one to expect government spending in these countries to display less of a countercyclical pattern than in industrial countries. For example, Gavin and Perotti (1997) note that Latin American countries spend much less on transfers and subsidies than do richer OECD economies (24 percent of total government expenditures, compared with 42 percent in the industrial countries). Similarly, Braun (2001) finds that 40 percent of the difference in the degree of cyclicality between high income and developing countries can be explained by the larger size of government in the former, and by the larger proportion of transfers in expenditure, which act as automatic stabilizers.

Liquidity constraints could also play a role in limiting the capacity for countercyclical policy: during economic downturns, countries often face a loss of market confidence, and thus intensified borrowing constraints. The loss of market access makes it impossible to run a countercyclical fiscal policy, at least in periods of sharp contractions in output. However, as Talvi and Végh (2000) point out, it would be somewhat far-fetched to argue that most developing countries have lost access to international credit markets during recessions on a systematic basis over the past three decades.

Another important factor behind the procyclicality of government spending relates to institutional factors and the underlying power structure of the economy. These considerations explain overspending of transitory increases in fiscal revenues (Velasco, 1993; Perotti, 1996; and Tornell and Lane, 1998 and 1999). This is commonly known as the "voracity" effect, 
whereby a positive shock to income leads to a more than proportional increase in public spending, even if the shock is expected to be temporary. This in turn is the consequence of weak institutions and fractionalization, manifested by the presence of multiple powerful groups in a society attempting to grab a greater share of national wealth by demanding larger public spending on their behalf. ${ }^{3}$ In a similar vein, Stein, Talvi, and Grisanti (1999) find that, for their Latin American sample, countries with a large number of representatives elected per district, a large number of effective parties represented in the legislature, and weak support for the governing party in the legislature are associated with a stronger procyclical response of government consumption to the business cycle. In this context, Lane (2003) finds that the political economy factors explaining the cyclicality of government spending in OECD countries vary in importance across spending categories, with the government wage bill being especially influenced by these variables. Braun (2001) finds that political competition among powerful groups is stabilizing in OECD countries, but destabilizing in developing countries.

The literature on fiscal cyclicality typically does not address whether there is a long-term relationship between government spending and output. A vast literature exists on "Wagner's law," which states that government activity increases as economies grow, with the pace of increase being different for different branches of government (Wagner, 1911). Wagner's law has been tested empirically for various countries using both time-series and cross-sectional data sets. ${ }^{4}$ Some of these tests have used the stationarity properties of the data, as well as cointegration analysis, to test whether there is a long-run relationship between income and government spending (Bohl, 1996; Lin, 1995; Murthy, 1993; Payne and Ewing, 1996; and Chang, 2002). The results are mixed, with studies finding a cointegrating relationship in some countries, but not in others. The cointegration approach is consistent with Wagner's view that there is a long-run relationship between government spending and output, without necessarily implying causality. However, this literature does not focus on short-run deviations from the long-term. The advantage of this paper is that both the short- and longrun relationships between government spending and output are assessed in a coherent framework.

\section{A Framework For Analyzing Co-Movements OF GOVERNMENT SPENDING AND OUTPUT}

Most studies analyzing the cyclicality of government spending and output have used a panel data methodology that has not fully exploited the time-series properties of the data. Studies testing for a long-run relationship such as "Wagner's law," on the other hand, have ignored

\footnotetext{
${ }^{3}$ Note that this does not necessarily refer to transfers to individuals or other levels of government, but can also include spending on infrastructure, wages, and other current spending which can benefit particular groups.

${ }^{4}$ See Chang (2002) for a brief summary of recent studies and Peacock and Scott (2000) for a critical review.
} 
the short-term aspects of this relationship. In terms of the literature on cyclicality, many studies use panel data models that are not well suited to explore short-term versus long-term relationships. Some notable exceptions are Lane (1998), who uses a single-country timeseries study; Arreaza, Sørensen, and Yosha (1999), who allow cross-country heterogeneity by exploring subsamples of their panel data; Sørensen, Wu, and Yosha (2001), who concentrate on U.S. state and local governments; and Braun (2001), who uses the generalized method of moments (GMM) technique for dynamic panel data models developed by Arellano and Bond (1991). However, none of these papers allows for unit roots in the regressors or cointegration between government spending and output. Other authors estimate cyclicality by assessing the correlation between Hodrick-Prescott (HP) filtered government spending and output. This approach is not followed in this paper because HP-based measures of cyclicality may be misleading when samples have different levels of volatility (Forbes and Rigobon, 1998). Since output volatility differs across countries, we favor a regression-based approach.

This study attempts to exploit both the time-series and cross-sectional aspects of developing country data using an error-correction framework. Fiscal and output co-movements are investigated in this paper by generalizing the two-stage approach proposed by Lane (2003). In the first stage, we estimate the elasticity of government spending with respect to output, based on country-by-country time-series regressions. However, in contrast to Lane, we use an error-correction approach, which allows us to distinguish between the short-term effect of output on government spending and any longer-term effect between these two variables. In the second stage, we use the estimated short-term elasticities as dependent variables in a cross-sectional regression that aims to explain the cross-country differences in these elasticities.

\section{A. Estimating the Relationship Between Government Spending and Output}

The cyclicality of government spending is typically defined in terms of how spending moves with the output gap. If government spending increases when there is a positive output gap (i.e., output is below its potential), then spending is countercyclical. This implies lower spending when output is high relative to its trend. If potential output were observable or easy to estimate, one could define countercyclicality as an above-average spending-to-output ratio whenever output was below its potential. However, measuring potential output is difficult, particularly in a developing country setting. As a result, one cannot properly discuss business cycles or cyclicality per se. Therefore, following much of the existing literature, we focus on co-movements of government spending and output as a proxy for cyclicality.

As a first step, we distinguish co-movements that are temporary in nature from comovements that reflect a steady-state or long-term path. Suppose there is a steady-state relationship between government spending and output given by

$$
G=A Y^{\delta}
$$


where $G$ represents government spending in real terms, $Y$ represents real output, and $\delta$ is the long-run, constant elasticity of spending with respect to output. Such a relationship would be consistent with "Wagner's law," particularly if $\delta$ is greater than 1. Equation (1) can also be written in linear form as

$$
\log G=a+\delta \log Y, \quad a=\log A
$$

If the adjustment of spending $(G)$ to its steady-state $(\bar{G})$ is gradual, then the level of spending will respond to transitory changes in output, and $G$ will move gradually toward its steady-state or equilibrium level. To capture this gradual move, we specify a general autoregressive distributed lag specification for spending category $i$ in period $t$ :

$$
\log G_{i t}=\mu+\alpha \log G_{i, t-1}+\beta_{0} \log Y_{t}+\beta_{1} \log Y_{t-1}+\varepsilon_{t},|\alpha|<1 .
$$

We can solve for the static, steady-state equilibrium by assuming that output is at its steadystate level, $\bar{Y}$, and ignoring the error term:

$$
\log \bar{G}=\frac{\mu}{1-\alpha}+\underbrace{\frac{\beta_{0}+\beta_{1}}{1-\alpha}}_{\delta} \log \bar{Y} .
$$

More generally, we could allow output to grow at rate $g$. In this case, the only difference is that the constant term becomes $\frac{\mu+\left(\beta_{0}-\delta\right) g}{1-\alpha}$, which depends on $g$.

To reflect the steady state, equation (3) can be rearranged as an error-correction model:

$$
\Delta \log G_{i t}=\mu+\beta_{0} \Delta \log Y_{t}+\gamma\left[\log G_{i, t-1}-\delta Y_{t-1}\right]+\varepsilon_{t} .
$$

One can interpret $\beta_{0} \Delta \log Y_{t}$ as the short-term impact of output on spending and $\beta_{0}$ as the short-run elasticity of government spending with respect to output. The error correction term $\gamma\left[\log G_{i, t-1}-\delta \log Y_{t-1}\right]$ captures deviations from the steady-state, or long-run equilibrium, where $\delta$ is the long-run elasticity of government spending with respect to output, and $\gamma$ is the rate at which government spending adjusts to past disequilibrium. Moreover, equation (5) can be used to test if there is a long-run relationship between government spending and output. If so, then output and government spending are said to be cointegrated, and $\gamma$ will be significantly different from zero. ${ }^{5}$ If output and government spending are nonstationary and there is a cointegrating relationship between them, then a simple ordinary least squares (OLS) regression of government spending on output would yield the long-run elasticity of spending with respect to output, $\hat{\delta}$, which is superconsistent. Therefore, we estimate

\footnotetext{
5 Note that this test involves nonstandard critical values (see Ericsson and McKinnon, 2002). Given data constraints, we have assumed that output is weakly exogenous.
} 
equation (5) in two stages: (i) we run an OLS of government spending on a constant term and output and collect the residuals, and (ii) we place these residuals as the error correction term in equation (5).

The above derivation makes clear the underlying assumption that there is a constant elasticity relationship between output and expenditure, while the transitory deviations are random. In cases where $\gamma$ is insignificant, there is no steady-state relationship between government spending and output, and $\beta_{0}$ is best estimated by omitting the error correction term as follows:

$$
\Delta \log G_{i t}=\mu+\beta_{0} \Delta \log Y_{t}+\varepsilon_{i t} .
$$

\section{B. Modeling Cross-Country Variation in Fiscal Cyclicality}

The rest of the econometric methodology is a generalization of the procedure used by Lane (2003). After estimating the error-correction model for each country as in equation (5), we save the estimates $\hat{\beta}_{0}$, which come from equation (5) for countries where there is a cointegrating relationship, or from equation (6) when $\gamma$ is insignificant. Next, to explain the cross-country variation in fiscal cyclicality, we estimate the following equation for each category of spending:

$$
\hat{\beta}_{0, j}=\alpha+\eta Z_{j}+v_{j}
$$

where $\hat{\beta}_{0, j}$ is the estimated cyclicality coefficient for country $j$ from equation (5) or (6) and $Z$ is a vector of country-specific variables. In particular, $Z$ includes output volatility; an index for power dispersion; per capita GDP in purchasing power parity (PPP) terms; the standard deviation of terms of trade volatility; and a measure of financing availability. The appendix provides a detailed description of the variables and their sources.

Output volatility is expected to increase the elasticity of output on government spending. In countries where there is inadequate control of spending (e.g., through effective fiscal rules or fiscal responsibility laws), and where there is significant output volatility, governments will spend as much as they can during upswings, as they know that such outlays will be curtailed during downturns. Another explanation given by Talvi and Végh (2000) is the propensity to spend increases with output volatility, owing to greater spending pressures during upswings. As a result, in the presence of political distortions, when output (and therefore tax collections) are temporarily high, the government will find it optimal to reduce tax rates in order to fend off spending pressures, but at the same time will inevitably see itself increasing government spending to respond to political demands. As such, governments facing high output volatility may find it optimal to pursue procyclical fiscal policies.

To capture the widely held view that the political structure interacts with budgeting institutions in determining fiscal outcomes, we include the average index $(0,1)$ of power 
dispersion for each country taken from Henisz (2000). This index considers the number of veto points, defined as the number of branches there are in the central government (executive; lower, and upper chambers of the legislature) and whether political control of these different branches is unified or held by different parties or coalitions. The index counts the number of veto points in the political system and the distribution of preferences across and within different branches of government. Power is more dispersed, the greater the number of veto points and the greater the division of control across different political parties. Although spending pressures ("voracity") may accompany increased power dispersion, it is expected that efficiency gains from improved governance and transparency outweigh any voracity effects. We therefore expect power dispersion to reduce the short-term elasticity of spending with respect to output in the case of developing counties. ${ }^{6}$

Following Fatás and Mihov (2003) and Lane (2003), to control for the level of economic development, GDP per capita has been included in the regression. As pointed out by Fatás and Mihov, poor countries may rely more often on discretionary fiscal policy, thereby inducing output volatility. Accordingly, output per capita is expected to have negative effects on the short-term elasticity of spending with respect to output.

We control for the economic vulnerability that countries face by including the standard deviation of the terms of trade and the size of government. Countries facing higher external vulnerability may want to insure against negative shocks by increasing the share of domestic spending in total output. For example, Rodrik (1998) argues that "Governments appear to have sought to mitigate the exposure to external risk by increasing the share of domestic output which they consume." Therefore, higher external vulnerabilities could lead to government spending being used as a stabilizer. Therefore, this variable is expected to decrease the short-term elasticity of spending with respect to output.

In order to capture how financing constraints affect the cyclicality of government spending, we include various measures of external financing constraints. For developing countries that do not have access to international capital markets, this relates mainly to the availability of official foreign financing. We therefore include the average share of official donor assistance as a share of gross national income. For emerging market countries with access to international capital markets, we use a measure of financial risk, reported by the International Country Risk Guide (ICRG), which is aimed at assessing the likelihood that a country will be able to service its foreign debt by assigning a numerical value to a predetermined range of

\footnotetext{
${ }^{6}$ For OECD countries, Lane (2003) also finds little support for the voracity hypothesis. Power dispersion was even found to be negatively associated with procyclicality in total government expenditure and capital expenditure.
} 
risk components, according to a preset weighted scale. ${ }^{7}$ This measure of risk could be expected to be correlated with borrowing costs, and hence provide a proxy for external financing constraints. For countries with high levels of financial risk-which would typically be expected to rise during a cyclical downturn - the scope for countercyclical fiscal policy is likely to be much reduced. As such, higher levels of risk are expected to have a positive effect on the short-term elasticity of spending.

\section{EMPIRICAL RESULTS}

The empirical analysis is conducted with a data set covering 51 developing countries for the period 1970-2002. ${ }^{8}$ The choice of countries is dictated by data availability. For the crosssectional regression, 16 countries were dropped from the sample, since data were not available for one or more regressors. The categories of public spending examined include total spending, current spending, government consumption (spending on goods and services), wage and nonwage government consumption, government capital spending, non-interest total spending, and non-interest current spending.

\section{A. Measuring the Short- and Long-Term Elasticity of Government Spending}

As a first step, Table 1 reports unit root tests for government spending and output for our sample of countries. Table 2 reports the estimates of the adjustment coefficient $\gamma$ from Equation (5), which are estimated by OLS with a correction for an autoregressive error term. In cases where $\gamma$ is significant, we conclude there is a cointegrating relationship between government spending and output. Table 3 reports the associated long-term elasticity, $\delta$. Table 4 reports the short-term elasticity between government spending and output. In cases where the error-correction term was insignificant, the coefficients reported are estimated using equation (6). The most salient results - some of which are different from the evidence from industrial countries-are as follows.

For most countries, there is a long-term relationship between government spending and output (Table 2). Although the error-correction term is significant in about 35 percent of countries in the sample for each spending aggregate, 80 percent of the sample countries have a significant error correction term for at least one of the spending aggregates. For example, the error-correction term is significant for spending on goods and services for Argentina,

\footnotetext{
7 The financial risk components include foreign debt as a percentage of GDP; foreign debt service as a percentage of exports of goods and services; current account as a percentage of exports of goods and services; net international liquidity in months of imports; and exchange rate stability.

${ }^{8}$ For a number of countries, fiscal data are available only for a much shorter time span.
} 
Table 1. Augmented Dickey Fuller Tests: Null hypothesis is that $\log (x)$ contains a unit root

\begin{tabular}{|c|c|c|c|c|c|c|c|c|c|c|c|c|c|c|c|c|}
\hline & Output & $\begin{array}{l}\text { Total } \\
\text { Spendi }\end{array}$ & & $\begin{array}{l}\text { Current } \\
\text { Spendin }\end{array}$ & & $\begin{array}{l}\text { Spendir } \\
\text { on Goo } \\
\text { and } \\
\text { Service }\end{array}$ & & $\begin{array}{l}\text { Wages } \\
\text { Salarie }\end{array}$ & $\begin{array}{l}\text { and } \\
\text { es }\end{array}$ & $\begin{array}{l}\text { Other } \\
\text { Goods } \\
\text { Service }\end{array}$ & & $\begin{array}{l}\text { Capital } \\
\text { Spendin }\end{array}$ & & $\begin{array}{l}\text { Non- } \\
\text { Interest } \\
\text { Current } \\
\text { Spending } \\
\end{array}$ & $\begin{array}{l}\text { Non- } \\
\text { Interest } \\
\text { Total } \\
\text { Spendi }\end{array}$ & \\
\hline Argentina & -2.11 & -1.96 & & -1.91 & & -7.35 & $* * *$ & -1.13 & & -2.58 & & -2.01 & & -2.383 & -2.35 & \\
\hline Burkina Faso & -2.34 & -2.13 & & -3.02 & & -2.56 & & -2.49 & & 1.11 & & -1.59 & & -3.156 & -2.36 & \\
\hline Bulgaria & 0.56 & -1.66 & & -1.68 & & -3.36 & & -0.98 & & -4.63 & $* * *$ & -5.23 & $* * *$ & -0.586 & -0.95 & \\
\hline Bolivia & -1.48 & -1.25 & & -1.30 & & -2.13 & & -2.29 & & -2.91 & & -1.41 & & -1.652 & -1.30 & \\
\hline Barbados & -3.39 & -1.05 & & -0.64 & & 2.27 & & -5.75 & $* * *$ & -0.70 & & -2.17 & & $-4.805 * * *$ & -3.40 & \\
\hline Bhutan & -2.00 & -1.98 & & -2.73 & & -3.09 & & -3.30 & & -2.87 & & -0.95 & & -2.433 & -2.14 & \\
\hline Cameroon & -2.70 & -3.77 & $* *$ & -4.31 & $* * *$ & -4.33 & $* * *$ & -4.32 & $* * *$ & -3.41 & $* *$ & -2.39 & & $-4.653 * * *$ & -3.79 & $* *$ \\
\hline Chile & -2.65 & -0.54 & & 1.33 & & 0.39 & & 1.11 & & -1.08 & & -1.27 & & 0.771 & -0.98 & \\
\hline Colombia & -1.34 & -2.51 & & -1.90 & & -2.34 & & -6.82 & $* * *$ & -1.43 & & -1.44 & & -2.503 & -2.62 & \\
\hline Congo, Rep. of & -1.42 & -2.05 & & -2.04 & & -3.11 & & -2.10 & & -3.45 & $* *$ & -1.62 & & -1.767 & -1.58 & \\
\hline Costa Rica & -1.63 & -4.32 & $* * *$ & -4.30 & $* * *$ & -4.25 & $* * *$ & -4.34 & $* * *$ & -2.91 & & -3.83 & $* *$ & $-4.34 * * *$ & -4.32 & $* * *$ \\
\hline Cyprus & $-3.71 * *$ & -1.41 & & -2.84 & & -2.08 & & -1.07 & & -2.43 & & -2.15 & & $-4.112 * * *$ & -2.02 & \\
\hline Domican Rep. & -1.18 & -1.40 & & -0.96 & & -0.67 & & -0.87 & & -2.17 & & -2.07 & & -1.172 & -1.48 & \\
\hline Egypt & -1.66 & -1.86 & & -2.20 & & -2.33 & & -1.72 & & -2.69 & & -1.81 & & -1.985 & -1.78 & \\
\hline El Salvador & -1.65 & -2.16 & & -2.24 & & -2.23 & & -2.06 & & -2.36 & & -3.15 & & -2.409 & -2.24 & \\
\hline Ethiopia & -1.34 & -0.79 & & -0.58 & & -1.18 & & -1.07 & & -1.03 & & -2.07 & & -0.613 & -1.03 & \\
\hline Ghana & -2.23 & -2.26 & & -2.73 & & -2.16 & & -2.57 & & -2.47 & & -2.18 & & -2.689 & -2.12 & \\
\hline Guatemala & -1.62 & -1.95 & & -1.93 & & -2.07 & & -1.67 & & -1.97 & & -2.22 & & -1.584 & -1.58 & \\
\hline Hungary & -2.04 & -2.40 & & -1.57 & & -2.61 & & 0.38 & & -1.65 & & -1.96 & & -1.512 & -2.47 & \\
\hline India & -1.86 & -1.40 & & -1.41 & & -1.94 & & -3.10 & & -1.74 & & -1.79 & & -1.585 & -1.56 & \\
\hline Indonesia & -2.62 & -2.79 & & -2.82 & & -2.59 & & -2.02 & & -2.83 & & -2.33 & & -2.897 & -2.83 & \\
\hline Iran, I.R. of & -2.50 & -3.47 & $* *$ & -2.38 & & -2.18 & & -6.11 & $* * *$ & -1.54 & & -3.43 & $* *$ & -1.514 & -2.69 & \\
\hline Jordan & -1.25 & -2.47 & & -1.76 & & -1.83 & & -2.06 & & -2.17 & & -4.37 & $* * *$ & -2.524 & -3.40 & \\
\hline Lesotho & -2.33 & -2.32 & & -3.01 & & -4.17 & $* * *$ & -2.98 & & -4.32 & $* * *$ & -2.00 & & $-3.673 * *$ & -2.39 & \\
\hline Kenya & -1.56 & -3.28 & & -1.28 & & -1.91 & & -0.62 & & -2.66 & & -2.66 & & -0.97 & -1.96 & \\
\hline Madagascar & -1.80 & -3.46 & $* *$ & -3.16 & & -2.43 & & -2.65 & & -3.24 & & -3.30 & & $-3.81 * *$ & -3.55 & $* *$ \\
\hline Malawi & -0.33 & -2.03 & & -3.38 & & -1.34 & & -1.73 & & -0.78 & & -1.07 & & -1.2 & -0.56 & \\
\hline Mali & -2.33 & -1.95 & & -1.82 & & -2.76 & & -2.91 & & -2.27 & & -2.20 & & -2.026 & -1.98 & \\
\hline Mauritius & -2.88 & -1.51 & & -0.88 & & -0.62 & & -1.20 & & -2.34 & & -2.59 & & -0.817 & -1.65 & \\
\hline Mexico & -2.75 & -4.07 & $* * *$ & -3.57 & $* *$ & -3.24 & & -4.31 & $* * *$ & -2.26 & & -3.10 & & -2.879 & -3.50 & $* *$ \\
\hline Morocco & -2.74 & -1.40 & & -1.56 & & -1.30 & & -1.77 & & -1.83 & & -1.92 & & -1.407 & -1.40 & \\
\hline Namibia & -3.09 & -2.46 & & -2.08 & & -1.49 & & -1.69 & & -1.22 & & -2.85 & & -3.213 & -3.16 & \\
\hline Nicaragua & -1.66 & -1.89 & & -1.83 & & -2.01 & & -2.94 & & -0.37 & & -1.87 & & -1.811 & -1.88 & \\
\hline Pakistan & -0.11 & -0.17 & & -0.62 & & 0.57 & & -1.86 & & -0.72 & & -0.87 & & -0.142 & 0.50 & \\
\hline Panama & -1.93 & -1.83 & & -2.05 & & -1.93 & & -2.18 & & -1.89 & & -2.09 & & -2.025 & -1.74 & \\
\hline Papua New Guinea & -2.64 & -2.08 & & -2.21 & & -1.66 & & -2.28 & & -1.55 & & -1.84 & & -1.749 & -1.77 & \\
\hline Paraguay & -2.89 & -2.17 & & -1.75 & & -2.61 & & -2.10 & & -2.15 & & -2.99 & & -1.025 & -1.50 & \\
\hline Peru & -1.75 & -2.78 & & -2.34 & & -1.89 & & -3.32 & & -2.04 & & -2.10 & & -2.309 & -2.47 & \\
\hline Philippines & -2.09 & -1.57 & & -1.75 & & -1.56 & & -1.84 & & -3.01 & & -1.58 & & -1.661 & -1.54 & \\
\hline Romania & -2.11 & -2.72 & & -2.52 & & -2.58 & & -1.67 & & -2.40 & & -2.24 & & -2.486 & -2.06 & \\
\hline Solomon Islands & -2.68 & -5.37 & $* * *$ & -2.32 & & -2.64 & & -0.29 & & -3.08 & & -4.41 & $* * *$ & -2.051 & -5.07 & $* * *$ \\
\hline South Africa & -2.20 & -2.27 & & -2.40 & & -1.41 & & -0.53 & & -0.11 & & -2.04 & & -2.41 & -2.23 & \\
\hline Sri Lanka & 0.03 & -1.11 & & -0.87 & & -1.03 & & -1.39 & & -1.75 & & -1.63 & & -0.986 & -1.16 & \\
\hline Swaziland & -1.21 & -2.77 & & -3.27 & & -3.68 & $* *$ & -1.02 & & -3.88 & $* *$ & -2.16 & & $-4.012 * * *$ & -2.56 & \\
\hline Thailand & -2.85 & -2.19 & & -2.30 & & -1.52 & & -1.42 & & -2.13 & & -2.07 & & -2.583 & -2.15 & \\
\hline Tunisia & -1.84 & -1.46 & & -1.61 & & -2.49 & & -2.53 & & -2.41 & & -2.12 & & -2.479 & -2.32 & \\
\hline Turkey & -2.75 & -2.70 & & -3.20 & & -2.88 & & -1.80 & & -3.55 & $* *$ & -2.46 & & -3.101 & -2.58 & \\
\hline Uruguay & -2.95 & -3.45 & $* *$ & -3.27 & & -2.39 & & -2.65 & & -2.50 & & -2.94 & & -2.905 & -3.07 & \\
\hline Venezuela & -1.92 & -1.47 & & -1.18 & & -1.38 & & -0.97 & & -2.20 & & -2.44 & & -1.621 & -2.00 & \\
\hline Zambia & -2.17 & -3.32 & & -2.82 & & -5.67 & $* * *$ & -5.51 & $* * *$ & -3.40 & & -2.49 & & $-3.536 * *$ & -3.10 & \\
\hline Zimbabwe & -3.28 & -2.72 & & -2.75 & & -3.71 & $* *$ & -3.71 & $* *$ & -2.42 & & -1.84 & & -2.779 & -2.76 & \\
\hline Non-stationary cases & 50 & 44 & & 48 & & 44 & & 43 & & 45 & & 46 & & 43 & 46 & \\
\hline Stationary cases & 1 & 7 & 7 & 3 & & 7 & & 8 & & 6 & & 5 & & 8 & 5 & ; \\
\hline
\end{tabular}

** Significant at 5\%; *** significant at $1 \%$. 
Table 2. Error Correction Model: Estimates of Gamma - the Adjustment Coefficient 1/ $\Delta \log G_{i t}=\mu_{i}+\beta_{G i} \Delta \log Y_{t}+\gamma\left(G_{i t-1}-\delta Y_{t-1}\right)+\varepsilon_{i t}$

\begin{tabular}{|c|c|c|c|c|c|c|c|c|c|c|c|c|c|c|c|c|c|c|c|c|c|c|c|}
\hline \multirow[b]{2}{*}{1 Argentina } & \multicolumn{2}{|c|}{ Total Spending } & \multicolumn{3}{|c|}{ Current Spending } & \multicolumn{3}{|c|}{$\begin{array}{l}\text { Spending on } \\
\text { Goods and } \\
\text { Services }\end{array}$} & \multicolumn{3}{|c|}{$\begin{array}{l}\text { Wages and } \\
\text { Salaries }\end{array}$} & \multicolumn{3}{|c|}{$\begin{array}{l}\text { Other Goods and } \\
\text { Services }\end{array}$} & \multicolumn{3}{|c|}{ Capital Spending } & \multicolumn{3}{|c|}{$\begin{array}{l}\text { Non-Interest } \\
\text { Current Spending } \\
\end{array}$} & \multicolumn{3}{|c|}{$\begin{array}{l}\text { Non-Interest Total } \\
\text { Spending }\end{array}$} \\
\hline & -0.17 & $(0.15)$ & -0.18 & $(0.15)$ & & -0.20 & $(0.06)$ & $*$ & -0.61 & $(0.26)$ & & 0.16 & $(0.17)$ & & -0.46 & $(0.18)$ & & -0.36 & $(0.18)$ & & -0.27 & $(0.16)$ & \\
\hline 2 Burkina Faso & -0.45 & $(0.15)$ & -0.32 & $(0.15)$ & & -0.52 & $(0.18)$ & & -0.40 & $(0.30)$ & & -0.48 & $(0.51)$ & & -0.61 & $(0.21)$ & & -0.32 & $(0.15)$ & & -0.44 & $(0.15)$ & \\
\hline 3 Bulgaria & -1.27 & $(0.29) * *$ & -1.29 & $(0.28)$ & $* *$ & -0.99 & $(0.36)$ & & -0.85 & $(0.31)$ & & -1.02 & $(0.34)$ & $*$ & -0.63 & $(0.16)$ & $* *$ & -1.27 & $(0.33)$ & $* *$ & -1.14 & $(0.34)$ & $*$ \\
\hline 4 Bolivia & -0.39 & $(0.28)$ & -0.53 & $(0.33)$ & & -0.40 & $(0.23)$ & & -0.80 & $(0.27)$ & & -0.39 & $(0.23)$ & & -0.96 & $(0.25)$ & $* *$ & -0.74 & $(0.31)$ & & -0.53 & $(0.29)$ & \\
\hline 5 Barbados & -1.27 & $(0.23) * *$ & -0.26 & $(0.21)$ & & -1.47 & $(0.42)$ & $* *$ & -0.80 & $(0.40)$ & & -1.49 & $(0.22)$ & $* *$ & -0.43 & $(0.18)$ & & -0.43 & $(0.24)$ & & -0.64 & $(0.28)$ & \\
\hline 6 Bhutan & -1.21 & $(0.25) * *$ & -0.57 & $(0.19)$ & $*$ & -0.33 & $(0.19)$ & & -0.23 & $(0.16)$ & & -0.09 & $(0.19)$ & & -0.31 & $(0.21)$ & & -0.26 & $(0.18)$ & & -0.51 & $(0.21)$ & \\
\hline 7 Cameroon & -0.17 & $(0.05) *$ & -0.14 & $(0.05)$ & & -0.16 & $(0.05)$ & $*$ & -0.15 & $(0.06)$ & & -0.22 & $(0.04)$ & $* *$ & -0.29 & $(0.06)$ & $* *$ & -0.14 & $(0.05)$ & $*$ & -0.17 & $(0.05)$ & $* *$ \\
\hline 8 Chile & 0.04 & $(0.20)$ & -0.83 & $(0.33)$ & & -0.21 & $(0.25)$ & & -0.41 & $(0.27)$ & & -0.20 & $(0.10)$ & & -0.04 & $(0.10)$ & & -0.33 & $(0.34)$ & & 0.24 & $(0.21)$ & \\
\hline 9 Colombia & -0.75 & $(0.35)$ & -0.71 & $(0.38)$ & & -0.68 & $(0.40)$ & & 0.02 & $(0.19)$ & & -0.70 & $(0.43)$ & & -0.55 & $(0.24)$ & & -0.55 & $(0.36)$ & & -0.56 & $(0.33)$ & \\
\hline 10 Congo, Rep. of & -0.38 & $(0.16)$ & -0.52 & $(0.16)$ & $*$ & -0.61 & $(0.23)$ & & -0.57 & $(0.23)$ & & -0.69 & $(0.23)$ & $*$ & -0.16 & $(0.12)$ & & -0.47 & $(0.21)$ & & -0.52 & $(0.21)$ & \\
\hline 11 Costa Rica & -0.26 & $(0.12)$ & -0.25 & $(0.11)$ & & -0.30 & $(0.13)$ & & -0.30 & $(0.13)$ & & -0.37 & $(0.15)$ & & -0.72 & $(0.19)$ & $* *$ & -0.25 & $(0.11)$ & & -0.26 & $(0.12)$ & \\
\hline 12 Cyprus & -0.09 & $(0.05)$ & -0.17 & $(0.05)$ & $* *$ & -0.14 & $(0.04)$ & $*$ & -0.15 & $(0.06)$ & & -0.14 & $(0.07)$ & & -0.84 & $(0.17)$ & $* *$ & -0.20 & $(0.05)$ & $* *$ & -0.11 & $(0.05)$ & \\
\hline 13 Domican Rep. & -0.45 & $(0.14) *$ & -0.72 & $(0.20)$ & $* *$ & -0.56 & $(0.18)$ & $*$ & -0.62 & $(0.19)$ & $*$ & -0.59 & $(0.18)$ & $*$ & -0.46 & $(0.16)$ & & -0.61 & $(0.19)$ & $*$ & -0.44 & $(0.15)$ & $*$ \\
\hline 14 Egypt & -0.34 & $(0.20)$ & -0.27 & $(0.16)$ & & -0.35 & $(0.17)$ & & -0.44 & $(0.14)$ & $*$ & -0.39 & $(0.19)$ & & -1.10 & $(0.19)$ & $* *$ & -0.23 & $(0.13)$ & & -0.40 & $(0.20)$ & \\
\hline 15 El Salvador & -0.74 & $(0.19) * *$ & -0.68 & $(0.19)$ & $* *$ & -0.43 & $(0.19)$ & & -0.35 & $(0.19)$ & & -0.39 & $(0.18)$ & & -0.70 & $(0.20)$ & $* *$ & -0.59 & $(0.19)$ & $*$ & -0.66 & $(0.19)$ & $* *$ \\
\hline 16 Ethiopia & -0.53 & $(0.18)$ & -0.30 & $(0.15)$ & & -0.43 & $(0.18)$ & & -0.52 & $(0.19)$ & & -0.25 & $(0.16)$ & & -0.23 & $(0.13)$ & & -0.61 & $(0.19)$ & $*$ & -0.47 & $(0.17)$ & \\
\hline 17 Ghana & -0.50 & $(0.18)$ & -0.50 & $(0.17)$ & $*$ & -0.86 & $(0.19)$ & $* *$ & -0.72 & $(0.21)$ & $* *$ & -0.78 & $(0.22)$ & $* *$ & -0.63 & $(0.19)$ & $* *$ & -0.61 & $(0.18)$ & $* *$ & -0.56 & $(0.19)$ & $*$ \\
\hline 18 Guatemala & 0.00 & $(0.09)$ & 0.10 & $(0.09)$ & & 0.07 & $(0.16)$ & & -0.73 & $(0.22)$ & $*$ & 0.06 & $(0.17)$ & & -0.52 & $(0.25)$ & & 0.01 & $(0.09)$ & & -0.07 & $(0.10)$ & \\
\hline 19 Hungary & -0.30 & $(0.12)$ & -0.43 & $(0.21)$ & & -0.69 & $(0.20)$ & $* *$ & -0.21 & $(0.14)$ & & -0.63 & $(0.20)$ & $*$ & -0.18 & $(0.12)$ & & -0.50 & $(0.25)$ & & -0.34 & $(0.14)$ & \\
\hline 20 India & -0.65 & $(0.13) * *$ & -0.66 & $(0.12)$ & $* *$ & -0.87 & $(0.18)$ & $* *$ & -0.85 & $(0.19)$ & $* *$ & -0.64 & $(0.17)$ & $* *$ & -0.14 & $(0.10)$ & & -0.63 & $(0.12)$ & $* *$ & -0.61 & $(0.13)$ & $* *$ \\
\hline 21 Indonesia & -0.21 & $(0.11)$ & -0.41 & $(0.14)$ & & -0.32 & $(0.13)$ & & -0.30 & $(0.10)$ & $*$ & -0.24 & $(0.12)$ & & -0.17 & $(0.11)$ & & -0.41 & $(0.14)$ & & -0.22 & $(0.11)$ & \\
\hline 22 Iran, I.R. of & -1.52 & $(0.16) * *$ & -0.83 & $(0.20)$ & $* *$ & -0.48 & $(0.17)$ & & -0.35 & $(0.21)$ & & -0.96 & $(0.21)$ & $* *$ & -0.22 & $(0.11)$ & & -0.79 & $(0.20)$ & $* *$ & -0.21 & $(0.11)$ & \\
\hline 23 Jordan & -0.21 & $(0.12)$ & -0.25 & $(0.14)$ & & -0.08 & $(0.08)$ & & -0.24 & $(0.15)$ & & -0.15 & $(0.08)$ & & -0.23 & $(0.11)$ & & -0.21 & $(0.11)$ & & -0.21 & $(0.10)$ & \\
\hline 24 Lesotho & -0.17 & $(0.10)$ & -0.29 & $(0.14)$ & & -0.47 & $(0.17)$ & & -1.05 & $(0.18)$ & $* *$ & -0.68 & $(0.18)$ & $* *$ & -0.13 & $(0.08)$ & & -0.39 & $(0.16)$ & & -0.18 & $(0.10)$ & \\
\hline 25 Kenya & -0.39 & $(0.27)$ & -0.64 & $(0.35)$ & & -0.31 & $(0.24)$ & & -1.18 & $(0.30)$ & $* *$ & -0.27 & $(0.24)$ & & -0.37 & $(0.22)$ & & -0.37 & $(0.26)$ & & -0.41 & $(0.27)$ & \\
\hline 26 Madagascar & -0.33 & $(0.14)$ & -0.49 & $(0.17)$ & & -0.33 & $(0.13)$ & & -0.70 & $(0.14)$ & $* *$ & -0.49 & $(0.17)$ & & -0.34 & $(0.15)$ & & -0.40 & $(0.15)$ & & -0.30 & $(0.14)$ & \\
\hline 27 Malawi & -1.01 & $(0.27) * *$ & -0.42 & $(0.28)$ & & -0.60 & $(0.31)$ & & -0.62 & $(0.28)$ & & -0.76 & $(0.33)$ & & -1.19 & $(0.18)$ & $* *$ & -0.71 & $(0.32)$ & & -1.05 & $(0.28)$ & $* *$ \\
\hline 28 Mali & -0.82 & $(0.18) * *$ & -0.65 & $(0.16)$ & $* *$ & -0.17 & $(0.13)$ & & -0.17 & $(0.12)$ & & -0.95 & $(0.22)$ & $* *$ & -0.02 & $(0.06)$ & & -0.24 & $(0.14)$ & & -0.17 & $(0.11)$ & \\
\hline 29 Mauritius & -0.39 & $(0.14)$ & -0.24 & $(0.23)$ & & -0.42 & $(0.25)$ & & -0.49 & $(0.26)$ & & -0.68 & $(0.25)$ & & -0.57 & $(0.42)$ & & -0.32 & $(0.24)$ & & -0.41 & $(0.15)$ & \\
\hline 30 Mexico & -0.58 & $(0.15) * *$ & -0.65 & $(0.13)$ & $* *$ & -0.65 & $(0.18)$ & $* *$ & -0.53 & $(0.16)$ & $*$ & -0.93 & $(0.18)$ & $* *$ & -0.33 & $(0.14)$ & & -0.73 & $(0.15)$ & $* *$ & -0.62 & $(0.16)$ & $* *$ \\
\hline 31 Morocco & -0.93 & $(0.22) * *$ & -0.74 & $(0.18)$ & $* *$ & -0.79 & $(0.23)$ & $* *$ & -0.72 & $(0.24)$ & $*$ & -0.71 & $(0.24)$ & & -0.21 & $(0.18)$ & & -0.82 & $(0.22)$ & $* *$ & -1.03 & $(0.25)$ & $* *$ \\
\hline 32 Namibia & -0.64 & $(0.28)$ & -0.71 & $(0.27)$ & & 0.07 & $(0.38)$ & & 0.27 & $(0.33)$ & & -0.72 & $(0.41)$ & & -0.73 & $(0.31)$ & & -0.71 & $(0.35)$ & & -0.71 & $(0.33)$ & \\
\hline 33 Nicaragua & -0.10 & $(0.08)$ & -0.10 & $(0.08)$ & & -0.08 & $(0.07)$ & & -0.33 & $(0.20)$ & & -0.08 & $(0.10)$ & & -0.28 & (0.13) & & -0.10 & $(0.08)$ & & -0.11 & (0.08) & \\
\hline 34 Pakistan & -0.27 & $(0.13)$ & -0.29 & $(0.13)$ & & -0.37 & $(0.19)$ & & -1.56 & $(0.18)$ & $* *$ & -1.92 & $(0.24)$ & $* *$ & -0.39 & $(0.16)$ & & -0.24 & $(0.11)$ & & -0.20 & $(0.12)$ & \\
\hline 35 Panama & -0.28 & $(0.14)$ & -0.25 & $(0.12)$ & & -0.50 & $(0.16)$ & $*$ & -0.36 & $(0.11)$ & $*$ & -0.10 & $(0.14)$ & & -0.13 & $(0.08)$ & & -0.46 & $(0.13)$ & $* *$ & -0.88 & $(0.19)$ & $* *$ \\
\hline 36 Papua New Guinea & -0.19 & $(0.10)$ & -0.19 & $(0.11)$ & & -0.05 & $(0.06)$ & & -0.59 & $(0.19)$ & $*$ & -1.25 & $(0.17)$ & $* *$ & -0.27 & $(0.10)$ & & -0.16 & $(0.10)$ & & -0.15 & $(0.09)$ & \\
\hline 37 Paraguay & -0.36 & $(0.14)$ & -0.23 & $(0.13)$ & & -1.03 & $(0.18)$ & $* *$ & -0.29 & $(0.14)$ & & -0.33 & $(0.11)$ & $*$ & -0.29 & $(0.15)$ & & -0.30 & $(0.12)$ & & -0.39 & $(0.12)$ & $*$ \\
\hline 38 Peru & -0.45 & $(0.18)$ & -0.59 & $(0.12)$ & $* *$ & -0.92 & $(0.18)$ & $* *$ & -0.95 & $(0.22)$ & $* *$ & -1.11 & $(0.19)$ & $* *$ & -0.94 & $(0.19)$ & $* *$ & -0.69 & $(0.14)$ & $* *$ & -0.61 & $(0.18)$ & $*$ \\
\hline 39 Philippines & -0.14 & (0.09) & -0.15 & $(0.08)$ & & -0.16 & $(0.09)$ & & -0.26 & $(0.11)$ & & -0.43 & $(0.16)$ & & -0.37 & $(0.15)$ & & -0.17 & $(0.09)$ & & -0.15 & $(0.10)$ & \\
\hline 40 Romania & -0.09 & $(0.07)$ & -0.56 & $(0.15)$ & $* *$ & -0.87 & $(0.23)$ & $* *$ & -0.40 & $(0.18)$ & & -0.85 & $(0.24)$ & $* *$ & -0.20 & $(0.13)$ & & -0.48 & $(0.14)$ & $* *$ & -0.34 & $(0.13)$ & \\
\hline 41 Solomon Islands & -0.21 & $(0.23)$ & -0.11 & $(0.08)$ & & -0.21 & $(0.10)$ & & -0.17 & $(0.05)$ & $*$ & -1.02 & $(0.24)$ & $* *$ & -0.71 & $(0.27)$ & & -0.17 & $(0.11)$ & & -0.36 & $(0.27)$ & \\
\hline 42 South Africa & -0.27 & $(0.13)$ & -0.31 & $(0.13)$ & & -0.29 & $(0.13)$ & & -0.14 & $(0.17)$ & & -0.25 & $(0.14)$ & & -0.16 & $(0.11)$ & & -0.26 & $(0.13)$ & & -0.15 & $(0.11)$ & \\
\hline 43 Sri Lanka & -0.43 & $(0.18)$ & -0.28 & $(0.17)$ & & -0.25 & $(0.15)$ & & -0.21 & $(0.12)$ & & -0.47 & $(0.20)$ & & -0.56 & $(0.18)$ & $*$ & -0.29 & $(0.17)$ & & -0.41 & $(0.17)$ & \\
\hline 44 Swaziland & -0.44 & $(0.11) * *$ & -0.09 & $(0.10)$ & & -0.37 & $(0.15)$ & & -0.30 & $(0.12)$ & & -0.51 & $(0.19)$ & & -0.48 & $(0.14)$ & $* *$ & -0.21 & $(0.13)$ & & -0.48 & $(0.11)$ & $* *$ \\
\hline 45 Thailand & -0.24 & $(0.11)$ & -0.24 & $(0.12)$ & & -0.38 & $(0.15)$ & & -0.51 & $(0.16)$ & $*$ & -0.39 & $(0.16)$ & & -0.37 & $(0.10)$ & $* *$ & -0.25 & $(0.12)$ & & -0.24 & $(0.11)$ & \\
\hline 46 Tunisia & -0.08 & $(0.12)$ & -0.10 & $(0.12)$ & & -0.63 & $(0.16)$ & $* *$ & -0.55 & $(0.16)$ & $* *$ & -0.48 & $(0.16)$ & $*$ & -0.24 & $(0.12)$ & & -0.38 & $(0.14)$ & & -0.25 & $(0.12)$ & \\
\hline 47 Turkey & -0.69 & $(0.17) * *$ & -0.44 & $(0.16)$ & & -0.97 & $(0.14)$ & $* *$ & -0.86 & $(0.12)$ & $* *$ & -1.11 & $(0.18)$ & $* *$ & -0.85 & $(0.19)$ & $* *$ & -0.40 & $(0.16)$ & & -0.61 & $(0.18)$ & $* *$ \\
\hline 48 Uruguay & -0.21 & $(0.09)$ & -0.20 & $(0.09)$ & & -0.15 & $(0.09)$ & & -0.12 & $(0.08)$ & & -0.31 & $(0.13)$ & & -0.26 & $(0.11)$ & & -0.23 & $(0.11)$ & & -0.21 & $(0.10)$ & \\
\hline 49 Venezuela & -0.28 & $(0.11)$ & -0.18 & $(0.10)$ & & -0.26 & $(0.12)$ & & -0.30 & $(0.14)$ & & -0.24 & $(0.13)$ & & -0.69 & $(0.16)$ & $* *$ & -0.26 & $(0.12)$ & & -0.38 & $(0.12)$ & \\
\hline 50 Zambia & -0.24 & $(0.14)$ & -0.17 & $(0.11)$ & & -0.64 & $(0.39)$ & & -1.39 & $(0.35)$ & $* *$ & -0.45 & $(0.31)$ & & -0.48 & $(0.16)$ & & -0.73 & $(0.47)$ & & -0.59 & $(0.39)$ & \\
\hline 51 Zimbabwe & -0.69 & $(0.19) * *$ & -0.71 & $(0.20)$ & $* *$ & -0.76 & $(0.21)$ & $* *$ & -0.63 & $(0.22)$ & & -0.96 & $(0.17)$ & $* *$ & -0.93 & $(0.22)$ & $* *$ & -0.70 & $(0.20)$ & $* *$ & -0.63 & $(0.19)$ & \\
\hline Average & -0.45 & & -0.41 & & & -0.46 & & & -0.50 & & & -0.57 & & & -0.45 & & & -0.42 & & & -0.41 & & \\
\hline Average 2/ & -0.83 & & -0.65 & & & -0.71 & & & -0.70 & & & -0.89 & & & -0.74 & & & -0.62 & & & -0.64 & & \\
\hline Share significant & $29 \%$ & & $29 \%$ & & & $33 \%$ & & & $39 \%$ & & & $41 \%$ & & & $31 \%$ & & & $29 \%$ & & & $31 \%$ & & \\
\hline Avg. adjusted $R^{2}$ & 0.30 & & 0.24 & & & 0.28 & & & 0.29 & & & 0.34 & & & 0.34 & & & 0.25 & & & 0.31 & & \\
\hline
\end{tabular}

Standard errors in parentheses; * significant at $10 \%$; ** significant at 5\%; *** significant at $1 \%$.

1/ Ericsson and McKinnon (2002) critical values used.

2/ Average of significant coefficients only. 
Table 3. Error-Correction Model: Estimates of Delta - the Long-Term Coefficient $\Delta \log G_{i t}=\mu_{i}+\beta_{G i} \Delta \log Y_{t}+\gamma\left(G_{i t-1}-\delta Y_{t-1}\right)+\varepsilon_{i t}$

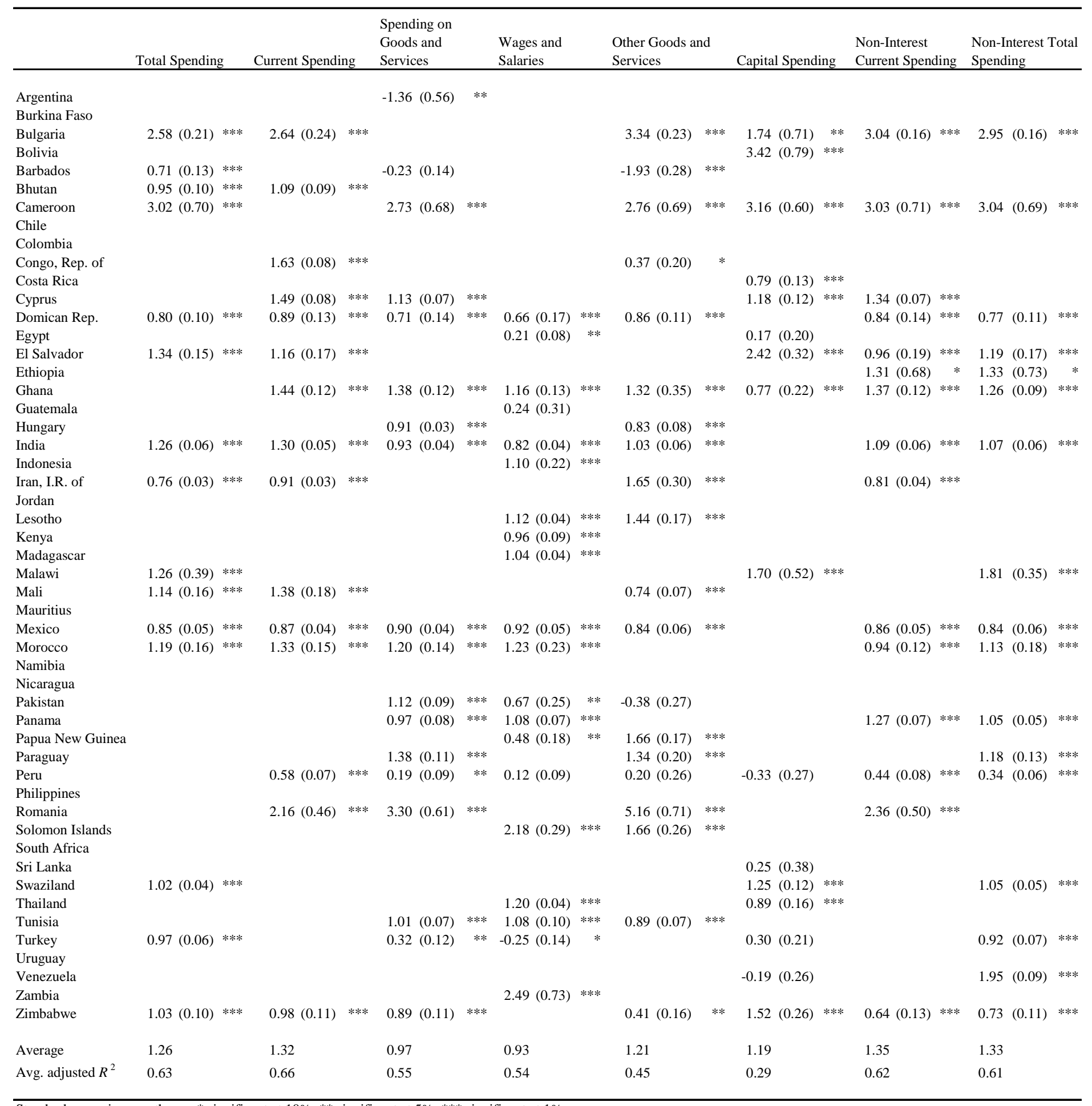


Table 4. Error-Correction Model: Estimates of Beta - the Short-Term Coefficient 1/

$\Delta \log G_{i t}=\mu_{i}+\beta_{G i} \Delta \log Y_{t}+\gamma\left(G_{i t-1}-\delta Y_{t-1}\right)+\varepsilon_{i t}$

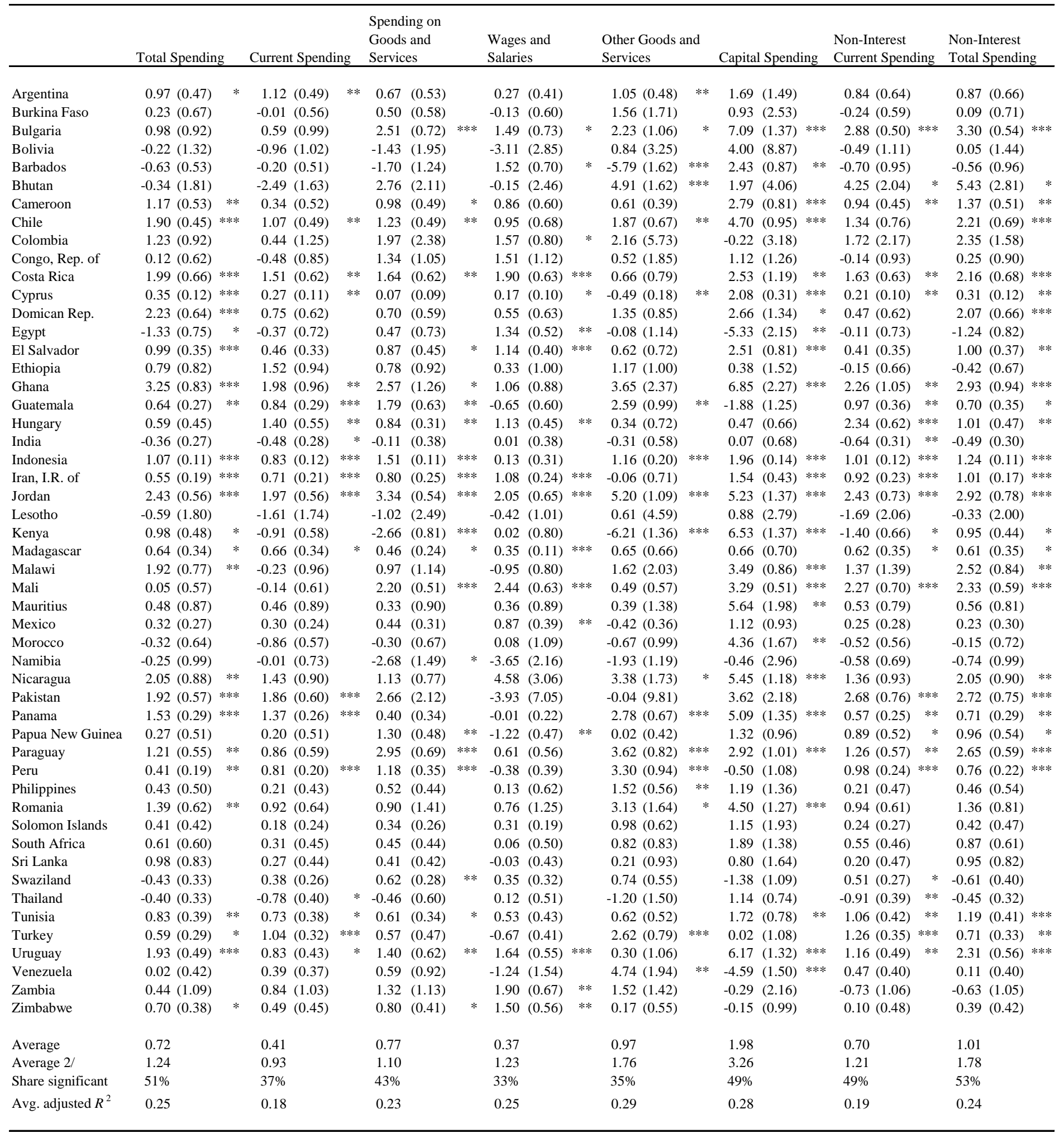

Standard errors in parentheses; * significant at 10\%; ** significant at 5\%; *** significant at $1 \%$.

1/ Error-correction model used only in cases where cointegration was found. See Table 2.

2/ Average of significant coefficients only. 
even though it is insignificant for the other spending aggregates. ${ }^{9}$ As expected, the adjustment coefficients are all negative, indicating dynamic stability. The implication of a significant errorcorrection term is that there is in fact a long-term relationship between government spending and output. The long-term elasticity of government spending and output, $\delta$, is on average greater than 1, consistent with "Wagner's law," and is highest for non-interest current and total spending (Table 3).

The short-run elasticity of government spending to output is positive in about half of the countries in the sample (Table 4). For all spending categories, the mean coefficient values are positive. For about 50 percent of the countries in the sample, the short-run elasticity of total spending is positive and statistically significant, with a mean coefficient above unity (1.24). When interest payments are excluded, 53 percent of countries show a large short-run elasticity, with a mean coefficient close to 2 (1.78). Capital expenditure exhibits the highest short-run elasticity, with a mean coefficient of 1.98 for the whole sample, and over 3 (3.26) for 49 percent of cases where the coefficient is significant. This implies that governments cut and expand capital investment proportionally more during recessions and expansions, respectively, than other types of spending. Current spending appears to have the smallest short-run elasticity, but it increases when interest payments are excluded. Overall, our findings contrast sharply with those obtained for industrial countries, which often suggest either a countercyclical behavior of fiscal policy or no clear pattern.

The size of the short-run elasticity with respect to output varies greatly across countries. Although the average coefficient estimate is positive for all spending categories, in many countries the relationship is not statistically significant. There are also cases where this elasticity is negative. For example, the short-run elasticity of non-wage current spending is strongly negative in Kenya and Barbados, the elasticity of capital spending is negative in Egypt and Venezuela, and the elasticity of non-interest current spending is slightly negative in India and Thailand.

When comparing the short-term and the long-run coefficients for countries where there is a long-term relationship between government spending and output, we find that on average the long-term elasticity is 75 percent larger than that for the short term. For capital spending, however, the short-term coefficient is larger than the long-term coefficient for 18 percent of the sample countries.

\section{B. Explaining Variations in Short-Term Elasticities Across Countries}

Following Lane (2003), cross-sectional weighted least square regressions were run using the reciprocal of the standard error of the coefficients estimated in the first step as weights. The

\footnotetext{
${ }^{9}$ Note that in cases where government spending is stationary, the interpretation of a long-term relationship between spending and output does not hold.
} 
results are summarized in Table 5. The key points emerging from this empirical analysis are as follows.

Power dispersion tends to dampen the short-term elasticity of government spending. The estimated coefficient is negative and statistically significant for all spending categories except for other goods and services. Our findings provide evidence on the effectiveness of institutional restrictions on fiscal policy, since the power dispersion index used in the regression is a measure of the political restraints (or veto powers by different institutions in a country) that limit policy discretion. The results do not support the voracity hypothesis, but rather imply that with a dilution of power comes a less procyclical response to shocks.

Volatility in a country's terms of trade appears to have no effect on the short-term elasticity of government spending. However, bigger governments have a smaller short-term elasticity of government spending. The coefficient estimate on government size is negative and significant for all spending categories except other goods and services and capital spending, consistent with OECD countries. This suggests that larger government spending plays a stabilizing role.

Financing constraints appear to play an important role in explaining cross-country differences in the short-term elasticity of spending, particularly for countries with access to international capital markets. The average share of official development assistance (ODA) in gross national income (GNI) has no significant impact on the short-term elasticity of government spending to output. This result implies that aid dependence does not contribute to the cyclicality of spending. In terms of external financing via capital markets, we find that the short-term elasticity of government spending is higher in countries with higher financial risk. This implies that countries with high financial risks have little scope to undertake countercyclical fiscal policies.

Output volatility has a positive effect on the short-term elasticity of spending on goods and services, indicating that countries with a high income volatility have a higher propensity to spend during good times. This result is also in line with Talvi and Végh (2000), who derive a model in which governments facing high output volatility find it optimal to pursue procyclical fiscal policies.

Output per capita does not seem to have an important influence on the short-term elasticity of government spending, but is nevertheless significant for some spending aggregates. Other control variables were tested, including regional dummies, a trade openness indicator, and the Standard and Poor's rating, but these were neither jointly or individually significant. 
Table 5. Determinants of Fiscal Cyclicality 1/

\begin{tabular}{|c|c|c|c|c|c|c|c|c|}
\hline & $\begin{array}{l}\text { Total } \\
\text { Spending }\end{array}$ & $\begin{array}{l}\text { Current } \\
\text { Spending }\end{array}$ & $\begin{array}{l}\text { Spending on } \\
\text { Goods and } \\
\text { Services }\end{array}$ & $\begin{array}{l}\text { Wages and } \\
\text { Salaries }\end{array}$ & $\begin{array}{l}\text { Other Goods } \\
\text { and Services }\end{array}$ & $\begin{array}{l}\text { Capital } \\
\text { Spending }\end{array}$ & $\begin{array}{l}\text { Non-Interest } \\
\text { Current } \\
\text { Spending } \\
\end{array}$ & $\begin{array}{l}\text { Non-Interest } \\
\text { Total } \\
\text { Spending } \\
\end{array}$ \\
\hline GDP volatility & $\begin{array}{l}0.15 \\
(0.24)\end{array}$ & $\begin{array}{l}0.34 \\
(0.23)\end{array}$ & $\begin{array}{l}0.69 \\
(0.290) * *\end{array}$ & $\begin{array}{l}0.10 \\
(0.36)\end{array}$ & $\begin{array}{l}0.70 \\
(0.51)\end{array}$ & $\begin{array}{l}0.39 \\
(0.74)\end{array}$ & $\begin{array}{l}0.26 \\
(0.30)\end{array}$ & $\begin{array}{l}0.10 \\
(0.32)\end{array}$ \\
\hline Power dispersion & $\begin{array}{l}-1.98 \\
(0.785)^{* *}\end{array}$ & $\begin{array}{l}-1.41 \\
(0.783)^{*}\end{array}$ & $\begin{array}{l}-1.99 \\
(0.930)^{* *}\end{array}$ & $\begin{array}{l}-2.53 \\
(1.201)^{* *}\end{array}$ & $\begin{array}{l}-1.74 \\
(1.60)\end{array}$ & $\begin{array}{l}-4.11 \\
(2.250)^{*}\end{array}$ & $\begin{array}{l}-1.82 \\
(1.018)^{*}\end{array}$ & $\begin{array}{l}-2.47 \\
(1.027)^{* *}\end{array}$ \\
\hline Per capita GDP & $\begin{array}{l}0.00 \\
(0.000)^{*}\end{array}$ & $\begin{array}{l}0.00 \\
(0.000)^{*}\end{array}$ & $\begin{array}{l}0.00 \\
(0.00)\end{array}$ & $\begin{array}{l}0.00 \\
(0.00)\end{array}$ & $\begin{array}{l}0.00 \\
(0.00)\end{array}$ & $\begin{array}{l}0.00 \\
(0.00)\end{array}$ & $\begin{array}{l}0.00 \\
(0.00)\end{array}$ & $\begin{array}{l}0.00 \\
(0.00)\end{array}$ \\
\hline Public size & $\begin{array}{l}-0.03 \\
(0.017)^{*}\end{array}$ & $\begin{array}{l}-0.03 \\
(0.016)^{*}\end{array}$ & $\begin{array}{l}-0.06 \\
(0.020)^{* *}\end{array}$ & $\begin{array}{l}-0.04 \\
(0.026) *\end{array}$ & $\begin{array}{l}-0.05 \\
(0.04)\end{array}$ & $\begin{array}{l}-0.03 \\
(0.05)\end{array}$ & $\begin{array}{l}-0.04 \\
(0.021)^{*}\end{array}$ & $\begin{array}{l}-0.05 \\
(0.023) * *\end{array}$ \\
\hline Standard deviation terms of trade & $\begin{array}{l}0.00 \\
(0.00)\end{array}$ & $\begin{array}{l}0.00 \\
(0.00)\end{array}$ & $\begin{array}{l}-0.01 \\
(0.01)\end{array}$ & $\begin{array}{l}0.00 \\
(0.01)\end{array}$ & $\begin{array}{l}-0.01 \\
(0.01)\end{array}$ & $\begin{array}{l}-0.02 \\
(0.01)\end{array}$ & $\begin{array}{l}0.00 \\
(0.01)\end{array}$ & $\begin{array}{l}0.00 \\
(0.01)\end{array}$ \\
\hline Avg. ODA as share of GNI & $\begin{array}{l}-0.04 \\
(0.03)\end{array}$ & $\begin{array}{l}-0.04 \\
-(0.03)\end{array}$ & $\begin{array}{l}-0.04 \\
-(0.03)\end{array}$ & $\begin{array}{l}-0.01 \\
(0.04)\end{array}$ & $\begin{array}{l}0.00 \\
(0.06)\end{array}$ & $\begin{array}{l}0.07 \\
(0.08)\end{array}$ & $\begin{array}{l}-0.05 \\
(0.03)\end{array}$ & $\begin{array}{l}-0.04 \\
(0.03)\end{array}$ \\
\hline Financial risk & $\begin{array}{l}0.08 \\
(0.025) * * *\end{array}$ & $\begin{array}{l}0.05 \\
(0.025)^{*}\end{array}$ & $\begin{array}{l}0.06 \\
(0.028)^{* *}\end{array}$ & $\begin{array}{l}0.02 \\
(0.04)\end{array}$ & $\begin{array}{l}0.08 \\
(0.05)\end{array}$ & $\begin{array}{l}0.08 \\
(0.08)\end{array}$ & $\begin{array}{l}0.04 \\
(0.03)\end{array}$ & $\begin{array}{l}0.07 \\
(0.034)^{* *}\end{array}$ \\
\hline Constant & $\begin{array}{l}3.44 \\
(0.840) * * *\end{array}$ & $\begin{array}{l}1.89 \\
(0.824)^{* *}\end{array}$ & $\begin{array}{l}2.96 \\
(0.966) * * *\end{array}$ & $\begin{array}{l}1.76 \\
(1.29)\end{array}$ & $\begin{array}{l}3.48 \\
(1.875)^{*}\end{array}$ & $\begin{array}{l}4.46 \\
(2.590) *\end{array}$ & $\begin{array}{l}2.34 \\
(1.087)^{* *}\end{array}$ & $\begin{array}{l}4.03 \\
(1.134)^{* * *}\end{array}$ \\
\hline Observations & 35 & 35 & 35 & 35 & 35 & 35 & 35 & 35 \\
\hline Adjusted $R^{2}$ & 0.26 & 0.17 & 0.36 & 0.01 & 0.06 & 0.00 & 0.08 & 0.19 \\
\hline Root mean square error & 0.59 & 0.59 & 0.69 & 0.86 & 1.30 & 1.74 & 0.76 & 0.78 \\
\hline
\end{tabular}

1/ Estimated by weighted least squares, using the standard error of the estimated betas from the first stage as weights. Standard errors in parentheses; * significant at $10 \%$; ** significant at $5 \%$; ** significant at $1 \%$. 


\section{Conclusions ANd Policy ImPlications}

The main purpose of this paper is to examine the short- and long-term behavior of government spending with respect to output using an error-correction model. These estimates are then used to explain the observed cross-country variation in the short-run elasticity of spending. We find that the main components of government spending are procyclical in about half of all countries, the degree of which varies across spending categories. In addition, we show that output and government spending are cointegrated, implying a long-term relationship between government spending and output (in line with "Wagner's law"), for the majority of countries for at least one spending aggregate. Finally, we attempt to explain the factors that influence the short-term elasticity of spending and find that power dispersion and government size typically dampen the positive response of government spending to output in the short run. Financial risk and output volatility, on the other hand, contribute to procyclicality in government outlays.

Three policy implications can be drawn from this study. First, in many countries there may be scope for fiscal rules or fiscal responsibility laws that limit the discretion for procyclical fiscal policy during upswings in the business cycle. Second, a strengthening of checks and balancesthat is, a greater dispersion of power - is fully compatible with good economic policymaking, since it helps reduce the cyclicality of government outlays. Third, in many countries there is a long-term relationship between the level of output and government spending. In these countries, short-run cuts in spending, or surges in government outlays, will eventually be erased as the government spending/GDP ratio returns to its long-term average. In these countries, special care will need to be taken to ensure that spending cuts achieved over the short run are accompanied by longer-term structural reforms to ensure these savings are durable.

For future work, the following issues should be addressed. First, it would be useful to deepen the empirical analysis by distinguishing between good times and bad. Another issue that warrants further research is how IMF-supported economic reforms, with their emphasis on fiscal reforms, have affected the procyclical behavior of government spending in developing countries. Finally, the analysis could be extended by assessing the short- and long-term movements of revenues and fiscal balances. 


\section{Definitions and Sources of Variables}

Fiscal data are obtained from the IMF's Government Financial Statistics, while GDP, GDP deflators, and exchange rates are obtained from the IMF's International Financial Statistics. In a few cases where there is a gap in the series, we extrapolate by taking the average of the data at periods $t-1$ and $t+1$, to ensure continuous data. All fiscal variables are converted into constant prices using the CPI index, taken from the World Economic Outlook (WEO) database. We examine the following public spending variables: total spending, current spending, government consumption (spending on goods and services) and its breakdown into its wage and nonwage components, government investment, non-interest current government spending, and non-interest total government spending.

Regarding the explanatory variables used in the second stage, following Lane (2003) we include average output volatility, measured as the standard deviation of the GDP growth rate. In addition, we consider several control variables, including (i) average index $(0,1)$ of power dispersion for each country, taken from Henisz (2000); (ii) average output per capita taken from WEO data; (iii) the government size, measured as average government spending (government consumption plus government investment) as percent of GDP; (iv) the standard deviation of the terms of trade, taken from WEO data; (v) average share of ODA as a share of GNI, taken from WEO data; and (vi) a financial risk rating, reported by ICRG. This rating provides a means of assessing a country's ability to service its current and future obligations with respect to official, commercial, and trade debt. Ratings are compiled by assigning risk points to a pre-set group of factors. The higher the risk point total, the higher the risk. 


\section{References}

Agénor, P.R., and Montiel, P.J., 1996, Development Macroeconomics (New Jersey: Princeton University Press).

Agénor, P.R., McDermott, J., and Prasad, E.S., 1999, "Macroeconomic Fluctuations in Developing Countries: Some Stylized Facts,” IMF Working Paper 99/35 (Washington: International Monetary Fund).

Arreaza, A., Sørensen, B.E., and Yosha, O., 1999, "Consumption Smoothing Through Fiscal Policy in OECD and EU Countries.” In: Poterba, J.R., Von Hagen, J., (Eds.), Fiscal Institutions and Fiscal Performance (Chicago: University of Chicago Press).

Arellano, M., and Bond, S., 1991, "Some Tests of Specification for Panel Data: Monte Carlo Evidence and an Application to Employment Equations," Review of Economic Studies, Vol. 58, Iss. 194, pp. 277-97.

Barro, R., 1979, “On the Determination of the Public Debt," Journal of Political Economy, Vol. 87, No. 5, pp. 93-110.

Blanchard, O., and Fischer, S., 1989, Lectures in Macroeconomics (Cambridge: MIT Press).

Bohl, M.T., 1996, “Some International Evidence on Wagner's Law,” Public Finance, Vol. 51, pp.185-200.

Braun, M., 2001, "Why Is Fiscal Policy Procyclical in Developing Countries" (Harvard University).

Chang, T., 2002, “An Econometric Test of Wagner's Law for Six Countries Based on Cointegration and Error-correction Modeling Techniques," Applied Economics, Vol. 34, pp. 1157-69.

Ericsson, N., McKinnon, J., 2002, "Finite Sample Properties of Error Correction Tests for Cointegration," Econometrics Journal, Vol. 5, No. 2, pp. 285-318.

Fatás, Antonio, and Mihov, Ilian, 2003, "The Case for Restricting Fiscal Policy Discretion," The Quarterly Journal of Economics, Vol. 118, No. 4, pp 1419-48.

Fiorito, Riccardo, 1997, "Stylized Facts of Government Finance in the G-7," IMF Working Paper 97/142 (Washington: International Monetary Fund).

— Real Business Cycles Perspective,” European Economic Review, Vol. 38, pp. 235-69. 
Forbes, Kristin, and Roberto Rigobon, 1998, "No Contagion, only Interdependence: Measuring Stock Market Co-movements,” NBER Working Paper No. 7267 (Cambridge, Massachusetts: National Bureau of Economic Research).

Galí, Jordi, 1994, “Government Size and Macroeconomic Stability,” European Economic Review, Vol. 38, No. 1, pp. 117-32.

Gavin, Michael, and Roberto Perotti, 1997, "Fiscal Policy in Latin America," NBER Macroeconomic Annual, pp.11-71 (Cambridge, Massachusetts: MIT Press).

Henisz, Witold J., 2000, “The Institutional Environment for Economic Growth," Economics and Politics, Vol. 12, pp. 1-31.

Hercowitz, Zvi, and Michael Strawczynski, 2004, "Cyclical Ratcheting in Government Spending: Evidence from the OECD," Review of Economics and Statistics, Vol. 86, No. 1, pp. 353-61.

Kaminsky, Graciela L., Carmen M. Reinhart, and Carlos Végh, 2004, "When it Rains, it Pours: Procyclical Capital Flows and Macroeconomic Policies," NBER Working Paper (forthcoming).

Lane, Philip R., 1998, "On the Cyclicality of Irish Fiscal Policy," Economic and Social Review, Vol. 29, No. 1, pp. 1-17.

— , 2003, "The Cyclical Behavior of Fiscal Policy: Evidence from the OECD," Journal of Public Economics, Vol. 87, pp. 2661-75.

Lin, C., 1995, “More Evidence on Wagner's Law for Mexico," Public Finance, Vol. 2, pp. 267-77.

Lucas, R.E., and N.L. Stokey, 1983, "Optimal Fiscal and Monetary Policy in an Economy Without Capital,” Journal of Monetary Economics, Vol. 12, pp. 55-94.

Murthy, N.R.V., 1993, Further Evidence on Wagner's Law for Mexico: An Application of Cointegration Analysis," Public Finance, Vol. 48, pp.77-85.

Payne, James. E., and Bradley T. Ewing, 1996, “International Evidence on Wagner's Hypothesis: A Cointegration Analysis," Public Finance, Vol. 51, No. 2, pp. 258-74.

Peacock, Alan, and Alex Scott, 2000, “The Curious Attraction of Wagner's Law," Public Choice, Vol. 102, No. 1-2, pp. 1-17.

Perotti, Roberto,1996, "Redistribution and Non-Consumption Smoothing in an Open Economy," Review of Economic Studies, Vol. 63, pp. 411-33. 
Rodrik, Dani, 1998, “Why Do More Open Economies Have Bigger Governments?” Journal of Political Economy, Vol. 106, No. 5, pp. 997-1032.

Sørensen, B.E., Wu, L., and Yosha, O., 2001, "Output Fluctuations and Fiscal Policy: US State and Local Governments, 1978-1994," European Economic Review, Vol. 45, pp. 12711310.

Stein, Ernesto, Ernesto Talvi, and Alejandro Grisanti, 1999, "Institutional Arrangements and Fiscal Performance: The Latin American Experience," Chapter 5 in James R. Poterba and Jürgen von Hagen (eds.), Fiscal Institutions and Fiscal Performance (Chicago: University of Chicago Press).

Talvi, Ernesto, and Carlos A. Végh, 2000, "Tax Base Variability and Procyclical Fiscal Policy," NBER Working Paper 7499 (Cambridge, Massachusetts: National Bureau of Economic Research).

Taylor, J.B., and M. Woodford (eds.), 1999, Handbook of Macroeconomics (Amsterdam: North-Holland).

The PRS Group, International Country Risk Guide (ICRG), http://www.icrgonline.com.

Tornell, Aaron, and Philip R. Lane, 1998, "Are Windfalls a Curse? A Non-Representative Agent Model of the Current Account," Journal of International Economics, Vol. 44, pp. 83-112.

—_, 1999, "The Voracity Effect," American Economic Review, Vol. 89, pp. 22-46.

Velasco, Andres, 1993, "A Model of Endogenous Fiscal Deficits and Delayed Fiscal Adjustment," C.V. Starr Center for Applied Economics Working Paper No. 93-04 (New York University).

Wagner, A., 1911, "Staat in nationalökonomischer Hinsicht," Handwörterbuch der Staatswissenschaften, pp. 743-745, third edition, Book VII (Jena: Lexis). 